Meta

Journal des traducteurs

Translators' Journal

\title{
Exploring Cultural Difference Through Translating Children's Literature
}

\section{Eva-Maria Metcalf}

Volume 48, numéro 1-2, mai 2003

Traduction pour les enfants

Translation for children

URI : https://id.erudit.org/iderudit/006978ar

DOI : https://doi.org/10.7202/006978ar

Aller au sommaire du numéro

Éditeur(s)

Les Presses de l'Université de Montréal

ISSN

0026-0452 (imprimé)

1492-1421 (numérique)

Découvrir la revue

Citer cet article

Metcalf, E.-M. (2003). Exploring Cultural Difference Through Translating

Children's Literature. Meta, 48(1-2), 322-327. https://doi.org/10.7202/006978ar
Résumé de l'article

L'article, de nature descriptive, traite d'un projet de traduction fait en commun avec des étudiants américains. Le projet avait pour but d'explorer l'enchâssement culturel de la langue et la nature hermeneutique de la traduction. En refléchissant aux problèmes de la traduction liés à la litterature enfantine et en imitant la situation d'un traducteur professionnel, les participants ont mieux compris le fonctionnement de la langue et les complexités associées à la traduction. 


\title{
Exploring Cultural Difference Through Translating Children's Literature
}

\author{
EVA-MARIA METCALF \\ University of Mississippi, Oxford, United States \\ emetcalf@olemiss.edu
}

\begin{abstract}
RÉSUMÉ
L'article, de nature descriptive, traite d'un projet de traduction fait en commun avec des étudiants américains. Le projet avait pour but d'explorer l'enchâssement culturel de la langue et la nature hermeneutique de la traduction. En refléchissant aux problèmes de la traduction liés à la litterature enfantine et en imitant la situation d'un traducteur professionnel, les participants ont mieux compris le fonctionnement de la langue et les complexités associées à la traduction.
\end{abstract}

\begin{abstract}
This article is descriptive in nature, presenting a student-faculty project in which participants translated a short children's story from German into English in order to explore the cultural embeddedness of language and the hermeneutic nature of translation. By reflecting on issues surrounding the translation of children's literature and by imitating the situation of a professional translator, project participants gained insight into the workings of language and the complexities associated with translation.

\section{MOTS-CLÉS/KEYWORDS}

cultural differences, German to English translation, short story, student-faculty project
\end{abstract}

\section{The Project}

A few years ago, I had received funds connected with innovative teaching techniques to lead an independent-study student-faculty research project for third-year (intermediate-level) undergraduate students of German at an American university. The project consisted a group of four American students and myself, who met once a week to translate a simple children's story from German into English, the native language of the students. The idea was to produce a professional quality, publishable translation of a hitherto untranslated text closely mimicking the work of a professional translator.

Needless to say, our kind of translation was far removed from the run-of-themill translation practiced in the foreign-language classroom. We did not focus on language mechanics, i.e., we did not translate sentences in order to understand their meaning or to recognize or practice particular grammatical constructions. Understanding the form and content of the German children's story was an easy task indeed because of the lexical and grammatical simplicity of the chosen texts. Understanding the text was only the precondition for the ensuing work on how best to capture the meaning and flavor of the text and to establish the cultural context in which it had been situated originally and to replicate these in some way in the target language. The learning experience was aimed at a deeper understanding of the ways 
in which language conceptualizes the world and the difficulties we encounter in reconceptualizing it by transposing it into a different language and culture.

Because of the limited language abilities of the students who were to assume the role of professional translators with a certain level of comfort, the texts to be translated had to be very simple linguistically. Children's literature became a natural choice because of its relative linguistic simplicity. Its limited vocabulary, relatively simple syntax, its liberal use of illustrations, and the fact that the content often stays close to everyday life experiences of children made it more accessible to the learner than fiction or non-fiction written for adults. But there were more benefits in choosing children's literature. Its engaging plot, its tendency to render abstract or analytical thought in concrete images, its tendency to spell out concretely instead of inferring notions helps a reader unaccustomed to the culture. Moreover, children's literature's mission to socialize young readers into the thought patterns, codes, norms, values, and habits of a specific culture made it well-suited for a cross-cultural project of our kind. Our assumed role as translators forced us to detect and expose the cultural constraints imposed on children's literature in both cultures and, in the end, to heighten our awareness of the fact that we were likely to impose a second cultural filter on the story we were going to translate.

The cognitive and experiential horizons of the real and - as a consequence - the implied reader in children's literature is smaller overall than that of an adult reader, especially that of an educated adult reader. In this regard a student who is in the process of learning a foreign language and a newcomer in its culture has a great deal in common with a child reader. But the match is not perfect by any means; there exists an asymmetry between the student's mostly adult mindset and experiences and the implied reader's assumed lack thereof. In addition, the foreign student lacks the intimate knowledge of the physical, social, and moral worlds presented by and in the foreign language. This asymmetry can be overcome through the process of analyzing, interpreting, and re-encoding the story's content, images, and ideas. Children's literature itself has changed as well, making reading contemporary children's stories a more attractive proposition for students. More children's books than ever before address a dual audience of children and adults, which on the other hand comes with a dual challenge for the translator, who now has to address both audiences in the target language.

Students who do not have the bi-cultural vision required of a good translator may be blind to some of the challenges the foreign text presents. However, the deliberate effort that comes with the act of translation, namely to understand the story within its own context in order to render it in a comparable fashion in a new context in the target language counteracts this blindness to an extent. My role as project leader and informant about value systems and social realities in Germany at the time the story was written restored the bi-cultural vision to some extent. By being forced to compare and make decisions and resolve the existing disparities, the participating students became critical readers. Along with an understanding of the cultural differences they could glean from the text came a growing awareness of their own personal and cultural assumptions.

Beyond my desire to sensitize American students (who often have little to no experience of foreign cultures) to the role of language in the sense-making process, the project was also designed to make the learning experience more immediately 
meaningful and engaging. The task of translating an "authentic" text for possible publication gave students an incentive to excel, and the hands-on process of translation provided an avenue for experiential learning.

\section{The Process}

We began the project with some preparatory deliberations, such as trying to define the place of children and children's literature within the context of society and asking ourselves what would be needed for a professional quality translation of a short children's story. We discussed value-laden questions such as: What is childhood? What is a good children's book? What is a good translation? What is the function of the translator? What is the intended and implied audience of our translation? What might affect the translator's, editor's, and publisher's choices? Then followed a period of mostly serendipitous reading of and about German and American children's literature and theories of translation (based on resources in the college and local libraries, such as Eugene Nida, Peter Newmark, Zohar Shavit, Göte Klingberg) that helped us establish a working hypothesis of translation.

The mission of the project, i.e., furthering cross-cultural understanding, was deflected into our approach to translation. We were inspired by Mildred L. Batchelder's statement from 1972 reprinted in a local children's literature publication The Children's Book Bag, "Children of one country who come to know the books and stories of many countries have made a beginning toward international understanding." (The Children's Book Bag, Winter, 1990, p.1) But once confronting actual translations and translating, we soon realized that this statement might make a good battle cry for advocates, such as Mildred Batchelder or Jella Lepman, but that it had to be taken with a grain of salt. This statement does not consider the effects of the inevitable screening process a children's text undergoes in the hands of translators, editors, publishers, mediators and the reader which could offset or even prevent any cross-cultural influence from happening in the first place.

We became aware of the effects that an imposition of several screening processes could have on a text by examining excerpts from the British and American editions of Christine Nöstlinger's novel Konrad oder das Kind aus der Konservenbüchse (1975), both based on Anthea Bell's translation. The differences were striking. The first chapters of the Batchelder award-winning American edition were severely shortened (the first chapter was cut by a third) and generally streamlined to stress the action-based sequences in the story. Nöstlinger's anti-authoritarian and feminist message was toned down somewhat in the British and toned down considerably in the American version of the novel. The German illustrations that had been kept in the British translation had been replaced by domesticated American illustrations, placing the Vienna children in an all-American setting.

The theoretical background and the illustrative examples prepared us to approach our own translation with greater circumspection and with determination to work against the tendency to Americanize that seemed prevalent in American translations from the 1970s and 1980s. The fact that only 1.2\% of all books produced in the United States were translations in 1995 (Tomlinson, 1998, p. 14) compared to roughly 80\% in Finland during the same decade, as Riitta Oittinen points out (Oittinen, 2000, p. XIII)), produces a readership in the United States that has little knowledge of and 
a low tolerance for foreignness. Many of the books that are translated in the United States have gone through a rigid selection process based on projections of their potential adoption by consumers and their financial success. This results in a "natural" selection of books that are adaptable to the target culture.

A five-page short story by Susanne Kilian, "Jürgen Körner, 8 Jahre, 2. Schuljahr" published in 1971 in the anthology of children's literature, Geh, spiel mit dem Riesen served as the main text for the project. This short and simple story proved to be rewarding from a social and cultural point of view. Written in minimalist, rather terse prose, the first-person narrative gives readers glimpses into the life of a neglected 8year old boy. It tells us about his everyday life at home and in school caught within a web of abuse received and committed. Most sentences are main clauses, the longest syntactic feature is a simple combination of main and dependent clause and the vocabulary consists of the vocabulary of an eight-year-old not too articulate child. (In second language acquisition terminology the language used is at the intermediatelow to intermediate-mid level)

Once we had read and discussed the story to gain an impression and compare our responses to it, we discussed the story's underlying concept of childhood and its ideological stance and message. Perceptions of the author's concept of childhood varied as did perceptions of the translator's attitudes toward implied readers. Which of our personal preferences should prevail? We were equally divided on what to do with the leftist ideology in a text that has little resonance in target culture. Should we retain it? Is adaptation a necessity, a self-preservation, or self-censorship?

Full of unresolved questions we approached the task of sentence-by-sentence translation. We all translated an assigned passage from the text individually and during meetings we compared and discussed our results. During the discussion sessions students had ample opportunity to vent their ideas again. Stylistic as well as semantic and ideological issues were soon at the heart of at times heated debates about target language renditions. Despite the simplicity of language and the limitations of content, the story contained an amazing amount of culturally specific information. Finding the right register, tone, and rhythm was not as simple as it had seemed originally. Perhaps the greatest challenge was posed by culturally specific words and concepts. How do we translate personal and geographic names, food items, games, and traditions that do not exist in the target culture? How do we render words like "Pausenbrot" which is not the same as a lunch pail, since school lunch does not exist in Germany? "Schulranzen" was equally untranslatable with backpack. It does get the message across that German children wear their school bags on the back, but it does not relay the message of expected neatness and home supervision of homework upon which the story hinges. We kept backpack and tried to stress the neatness with which papers and pencils are stored in other ways. How do we explain the importance of the pre-Christmas tradition of the German "Adventskranz" to American readers, since the full understanding of the story hinges on it? A footnote explanation seemed clumsy, but I believe, we opted for it. For the most part, our conflicting views were resolved in a compromise position on translation and resulted in a more-or-less consistent translation. However, it brought to the fore the culturally determined and subjective quality of translation, which was the sought-after learning experience.

Most of our discussions led us back to the fundamental question translators have posed themselves for centuries. How does one translate a set of different norms 
and values, an unfamiliar body of references and connotations, and culturally specific expressions and concepts and make it seem comfortable for the reader without losing its cultural significance? These discussions that strike at the heart of translation also took us far afield into the history, politics, and everyday life of both cultural areas.

\section{The Outcome}

In the end, we did not publish our translation, although it had been one of the aims of our project. It was after all not the product (although an important impetus for the project) but the process that counted, and it was the process that provided the learning experience. Putting the translation on the web and challenging others to improve it, would have been a great idea, and one I would like to pursue in the future. However, the project led to research papers, which the students presented at a national conference for undergraduate research the following semester.

The focus of these papers was an attempt to find an answer to the questions we had debated as we decided on our translation. To a large extent, students opted against adaptation to the target culture and making the text more reader-friendly and for keeping intact much of the otherness of the foreign culture in their translation. Their efforts to shape their translations so that American children could gain a broader vision by experiencing difference and in that manner gain a modicum of cross cultural knowledge was clearly a political decision on their part at a time when multiculturalism and emerging globalization became household words. It underlined the fact that translation will always be subject to political, moral, social, economic, cultural, religious, ideological, psychological and other pressures that have to be acknowledged. Because of children's literature's perceived mission to educate, the young students felt inclined to slip into the role of educator as translator, which seems to be a role not unfamiliar to many translators, editors and publishers of chjldren's literature. This attitude has - at least in the United States - produced exceedingly acculturated translations of children's stories, which are much less reprehensible and blander than the original texts.

Some results of the project were expected, others seemed like an added bonus. It goes without saying that the project improved the linguistic ability of the students. Working closely and creatively with language improved their command of grammar and vocabulary and their sensitivity to register and style. Making the role of the translator visible also enhanced their love of language and respect for the translator's craft. By the end of the project students' appreciation for the complexity of translation had grown manifold. The teamwork of a joint translation harnessed competitiveness into cooperation. Students became experts by embarking on a professional translation from simple German into English and could and did take pride in their work. Finally, is there a better way of learning than learning from experience?

\section{REFERENCES}

Kilian, S. (1971): “Jürgen Körner, 8 Jahre, 2. Schuljahr," in Geh, spiel mit dem Riesen. Weinheim und Basel: Beltz \& Gelberg pp. 277-282.

KLINGBerg, G. (1986): Children's Fiction in the Hands of the Translators. Lund: CWK Gleerup. Newmark, P. (1988): Approaches to Translation. New York, et al.: Prentice Hall. 
Nöstlinger, C (1976): Conrad. Illustr. Frantz Wittkamp, Übers. Anthea Bell. London: Andersen Press.

Nöstlinger, C. (1975): Konrad oder Das Kind aus der Konservenbüchse. Hamburg: Oetinger.

NöstLinger, C. (1977): Konrad Illustr. Carol Nicklaus. Übers. Anthea Bell. New York, London: Franklin Watts.

Oittinen, R. (2000): Translating for Children. New York, London: Garland.

O’Sullivan, E.: “Kinderliterarische Übersetzen" in Fundevogel 93/94, Dezember/Januar 1991/92 pp. 4-9.

Shavit, Z. (1986): “Translation of Children's Literature" in Poetics of Children's Literature. Athens and London: The University of Georgia Press, pp.111-130.

TomLinson, C. M. (1998) Children's Books from Other Countries. Lanham, MD, London: Scarecrow Press. 